\title{
Transnational educational research in four countries: Promoting Critical border praxis
}

\author{
Timothy G. Cashman \\ University of Texas at El Paso \\ Corresponding author: tcashman@utep.edu
}

DOI: https://doi.org/10.37134/jrpptte.vol9.no1.5.2019

Received: 11 Mac 2019; Accepted: 13 May 2019; Published: 27 Jun 2019

\begin{abstract}
This research took place in the following four countries: Malaysia, Mexico, Canada, and the United States (US). Educators in each country reported on how they addressed US international policies in their respective curricula. Critical border praxis emerged as a theoretical construct as a result of these transnational studies. Critical border praxis provides a contemplation of the intersection of place-based and border pedagogies, as well as how pedagogies are central to understanding one's own situated-ness. The findings of this study include recommendations for additional in-depth discussions of international policies in the US social studies curriculum. Implications for educators elsewhere are also articulated.
\end{abstract}

Keywords: Border pedagogy, critical border praxis, place-based pedagogies, transnational education

\section{INTRODUCTION}

This cross-comparative study explores how United States (US) foreign policies, including US conflicts, have been taught in various settings. The research considers how to add breadth to the US social studies curriculum through wider understandings of border pedagogy and place-based pedagogies. Included in this study are empirical analyses of data collected from educators and schools in Malaysia, Mexico, Canada, and the United States (US).

The first study took place in Sabah, Malaysia, with a study of Malaysian educators that transpired during and after a visit coinciding with the onset of the Iraq War. In Sabah the researcher witnessed the televised bombing of Baghdad, and wondered how Malaysian educators would teach about the attacks launched on Iraq. This initial study, based on personal concerns for how US international policies were being taught in transnational settings, led to research in other settings. If say, for example, Malaysian educators led discussions on whether or not the root causes of terrorism were being discussed in educational settings, would this hold also be a concern for classroom discussions in other countries, including the US? Subsequent research in Chihuahua, Chihuahua, Mexico was undertaken before drug cartel wars kicked into high gear in that country. A third study was conducted with educators in Eastern Ontario, Canada secondary schools. Interviews, surveys, and focus group sessions were facilitated at three different school sites along the Canada and US border. Finally, the researcher carried out a case study of how US educators teach transnational issues, including conflicts, at a high school on the US and Mexico border. The US study provided a snapshot of how teachers addressed US policies at that particular US secondary school site.

Personal connections with issues can be the impetus for the development of research questions. The researcher felt inextricably linked to global events during March, 2003, while visiting future in laws in Sabah, Malaysia. On March 20, 2003, at approximately 5:35 AM Baghdad time, United States (US) bombs fell on Baghdad, Iraq. This initial attack was followed by days of severe bombing in Baghdad and other cities, coinciding with the invasion of US and British ground forces 
in Iraq (Brunner, 2006). The unilateral actions were followed by huge protests in cities and towns across the US and around the globe.

As a visitor to Malaysia, a Muslim majority country, the researcher was concerned over the possible reception by local citizens, both Muslims and non-Muslims. Indeed, events during the onset of the war became a catalyst for gaining insight on how the US invasion of Iraq and other momentous decisions of the US government impacted lives of teachers and their students in Malaysia. The researcher interviewed educators in Sabah, Malaysia, during June and July of 2003. Follow-up electronic communications with educators took place throughout the rest of 2003.

A decision was made to build on the study of teachers in Malaysia with comparisons of educators' perspectives in Mexico and Canada. The study in Mexico transpired in Chihuahua, Chihuahua, a state that borders the US. The Canadian sampling of teachers followed as research occurred in two eastern Ontario communities near the US border. Finally, the researcher sought to compare teaching approaches of US social studies educators at a US high school on the US and Mexico international border.

It should be noted that research was completed in Malaysia and Mexico during the George H. W. Bush presidency; the data were collected in Canada and the US during the first Obama administration. Guiding the research in all four cases was the desire to uncover comparative aspects of social studies educators who teach of US policies in their respective curricula. Accordingly, Phillips and Schweisfurth (2006) put forth, "To some extent everyone is a comparativist," and the researcher set out to find the investigators in all of us, who seek to compare situations in familiar settings with environs less recognizable. Epstein (2008) argues that comparative education is an important endeavor because through comparative education we better comprehend and gain insight into the nature of our own education. Throughout the research in various settings educators reported on how classroom discussions ensued. This research sought to uncover the following: What perspectives do educators in Sabah, Malaysia; Chihuahua, Mexico; eastern Ontario, Canada, and the US/Mexico border bring to classroom discussions of US policies, including recent US-led wars and anti-terrorism measures? What do educators report as salient issues for students in their classroom discussions?

Research has indicated that there should be more candid, open dialogue on the effects of recent wars in US classrooms (Flinders, 2005; Davis, 2005). According to Davis (2005), American students do not engage in discussions of recent wars as much as they should. Moreover, Davis maintains that "the school curriculum appears to be especially mute about this [the Iraq] war" (2005, p. 186). For the purposes of this study, the investigator searched for perspectives that may have been lacking in the US school curriculum.

\section{PURPOSE OF THE STUDY}

Interviews took place with educators in Malaysia, Mexico, Canada, and the US to better understand discourses with regard to US international policies in schools from three separate countries and compare their teaching with the case of a US school site. The researcher sought to provide additional comparative insight for those who educate on common issues in US classrooms. The investigator sought to address the following question: "How is the US curriculum enhanced through understandings of border pedagogy and transnational, comparative studies?"

This study provides perspectives on the impact of major US policies, including the ongoing War on Terrorism. Indeed, some of these perspectives help fill the information void that has resulted from selective US mainstream media censorship of war and terrorism perspectives.

Educators in all four settings were asked the following questions:

1. How much time is devoted to the discussion of US policies?

2. How much open discourse exists in classrooms? 
3. What, if any, ideological differences are evident in classrooms during their discussions that included US policies?

4. How have discussions of US policies changed over recent years?

5. Why are perspectives from other countries' social education classrooms important for US social studies?

\section{Transnational Dialogue}

As stated earlier, research for this cross-comparative study began post-September $11^{\text {th }}, 2011$, in Sabah, Malaysia, and continued through two US presidential administrations. In the current Malaysian context, Goh and Wong (2015) argue that, in terms of pedagogy, teacher educators can and do play a significant role in assisting pre-service teachers and newly qualified teachers. They recommend teacher educators reflect on their practices and critique practices from different perspectives. In this manner, they are better qualified to model goals, standards and knowledge informed through research and practice. Hoon, Dziauddin, Jabar, Daud, Abd Rahman, and Othman (2014) recommend reviewing and evaluating the current policies, curriculum and practices of teaching and learning as well as assessment of social science education in Malaysian schools to promote higher social science literacy. Social sciences should be at the forefront of efforts to ameliorate social conditions both local and global conditions. Ratnavadivel, Nagappan, Dawi, and Lim (2014) put forth teacher education and pedagogical practices must continue to transform according to the needs and values of stakeholders in our society. Their research found that teacher education should take note of present societal concerns and respond appropriately. Changes to the existing system should be conducted in a timely, systematic, and comprehensive manner. In Malaysia, as well as Mexico, Canada, and the US, it is vital that we comprehend the physical, cultural, historically constructed, and socially organized senses of place.

Gruenewald (2003) argues that a pedagogy of place promotes understandings of social and ecological places. By incorporating critical approaches into place-based pedagogies, "we challenge the assumptions, practices, and outcomes taken for granted in dominant culture and in conventional education" (Gruenewald, 2003, p. 3). Gruenewald's critical pedagogy of place, therefore, links pedagogy of place with critical theory. A critical pedagogy of place stands in contrast with the survival-of-the-fittest educational philosophy that currently prevails in much of the US.

Border pedagogy builds upon critical understandings of place and attempts to connect those understandings with larger contexts. According to Giroux (2005), there are three components of border pedagogy that indicate a respect for differences: (a) a recognition of margins, (b) the need for border crossers, and (c) a recognition of the historically and socially-constructed strengths and limitations of places and borders. Borders are considered boundaries of entities, while the act of crossing borders involves going beyond existing boundaries and broadening one's perspectives of others in locales near or afar. Border pedagogy serves as a reconceptualization of existing ideologies and offers opportunities for students to engage the multiple references that constitute different cultural codes, experiences, and languages (Giroux, 2005). Border pedagogy provides possibilities for recognizing and contemplating historical contexts of our differences. As stakeholders in educational processes, teachers and students traverse languages, experiences, and voices and undergo changes in their own personal identities (Giroux, 2005).

The dynamics of what occurs in transnational classrooms can be considered through the lenses of border pedagogy. According to Giroux (1991) border pedagogy can be defined as an approach that provides opportunities for students to engage with the strengths and limitations of cultural and social codes that define their own histories and narratives. Therefore, students are empowered to become border-crossers who move in and out of physical, cultural, historically constructed, and socially organized borders. Border pedagogy allows students to draw upon their own personal experiences as real knowledge. As a pedagogical approach, it provides students opportunities to speak, to locate themselves in history, and to become subjects in the construction of their identities and the wider society.

Giroux (1991) put forth that border pedagogy teaches students the skills of critical thinking, debating power, meaning, and identity. The goals of transformative education are embedded within 
the discourses of border pedagogy (Garza, 2007; Giroux, 1991; Romo \& Chavez, 2006). According to Romo and Chavez (2006) border pedagogy encourages tolerance, ethical sophistication, and openness. Border pedagogy particularly engages learners in "multiple references that constitute different cultural codes, experiences, and languages to help them construct their own narratives and histories, and revise democracy through sociocultural negotiation" (p. 143).

Border pedagogy has implications for curricula in locales outside the border, itself. Comparisons, contrasts, and reflections on transnational education help provide multifaceted learning. Garza (2007) found that educators developed mutual understandings after considering border pedagogies. Moreover, teachers and administrators discovered that they could inform and strengthen each other's educational practices through transnational, border engagement (Garza, 2007). Cervantes-Soon and Carrillo (2016, p. 299) maintain "a border pedagogy is possible on a grand scale in which (not only) the critical, but also the spiritual, emotional, and the marginal come together to rearticulate education for social transformation. In this manner, students in border settings can be empowered.

Critical border dialogism (Cashman, 2015) considers the interconnectness of place-based and border pedagogies as part of contemplating one's own positionality in the context of larger research, intellectual knowledge, appreciation, and learning. Moreover, critical border dialogism is based on following principles:

- heteroglossia, (Abraham, 2014; Bakhtin, 1981; Clark \& Holquist, 1984) as it counters any sort of unilateral and unidirectional voices. Bakhtin (1981) puts forth that individuals connect with a multiplicity of voices through dialogue;

- meliorism (James, 1906; Koopman, 2006), which combines pluralism with humanism and serves as the thesis that we, as beings, are capable of bettering ourselves and creating a better world;

- critical cosmopolitanism (Delanty, 2006; Mignolo, 2000a), as it is an argument for the geopolitical diversal and globalization from below;

- nepantla (Abraham, 2014; Anzaldua, 1987; Maffie, 2007; Mignolo, 2000b), as it serves as a form of indigenous knowledge that places people and things in border surroundings that are characterized by dynamism and fluidity;

- dialogic feminism (Puigvert, 2012; Yaeger, 1991), as it is exemplified by creative energies with its renunciation, resistance, and counter-hegemonic actions of patriarchy and other borders that seek to limit

- pragmatic hope (Koopman, 2006; Nolan \& Stitzlein, 2011; Shade, 2001), as it offers possibilities for a transcendence by our confrontation of the limitations currently imposed on our educational systems.

Reconstructionist approaches (Cashman, 2015) are needed for addressing the structural inequities in our present day schools. Likewise, critical border dialogism offers hope for addressing the concerns articulated within the correspondence principle theory of Bowles and Gintis (1976). The findings of their research put forth the internal organization of schools corresponds to the internal organization of a capitalist society's workforce in its structures, norms, and values. In this manner, hierarchal control in schools reflects the structure of the market economy. Accordingly, the dominant class has systematically subjugated diverse students of lower socioeconomic status. Consequently, there is a pressing need for challenging power relationships with its theoretical underpinnings in heteroglossia, meliorism, critical cosmopolitanism, nepantla, dialogic feminism, and pragmatic hope.

Educators, students, and cultural workers are empowered through the implementation of critical border dialogism as praxis. According to Freire (2005), praxis involves reflection and action to precipitate change. Therefore, praxis is a process through which theory and pedagogy are enacted; transformative objectives are conceptualized within the overarching goals of praxis in education. This definition of praxis follows Gramsci's (1971) recommendations for "commonsense" to be reformulated to turn common sense ideas into informed knowledge. Informed knowledge, in turn, must be turned into the philosophy of praxis and applied across educational settings. Critical border 
praxis engages educators, students, and cultural workers in teaching and learning the social contexts of our discord and propels us to enter discourses and problem solving that keep pace with our dynamic surroundings and allow us to move beyond our boundaries and perceived limitations. As Leonardo (2004) argues, there is a need for utopic thinking so that nightmares can be transformed into dreams.

\section{METHOD}

For the research conducted in Sabah, Malaysia, interviews and surveys were conducted with teachers who taught students from ages 15-18 in either social studies courses at secondary and preparatory schools or General Knowledge, a required interdisciplinary national curriculum course at first year Malaysian higher education institutes. Permission was obtained so that personal interviews and follow-up communications could be conducted with nine educators, who represented Malay, Chinese, Iban, Sino-Kadazan, KadazanDusun, and Indian cultures.

In Chihuahua, Mexico, face-to-face interviews, focus group discussions, and observations were conducted with 21 social studies teachers and 4 school administrators at two separate sites, one secondary school and one middle school. For the Canadian comparative case study, 10 secondary social studies teachers in three secondary schools in two Eastern Ontario communities volunteered to be surveyed and interviewed. At the US school site on the US and Mexico border eight instructors and two administrators agreed to participate in the study. At least one teacher participant represented each social studies course taught at the high school. The participants self-identified as two females (one Latina and one White) and eight males (five Latino, two White, and one Black).

Research employed methodologies that followed Stake's (2000) model for a substantive case study. Accordingly, a qualitative case study researcher assumes the role of a trustworthy interpreter and gatherer of interpretations. The case study researcher, in turn, records and, ultimately, reports on the constructed realities or knowledge gathered through empirical investigations.

The researcher reflected on impressions, data, records, and salient elements at the observed site, and outcomes of the study. Transcriptions were made of face-to-face interviews and focus group sessions with participants. The study also included logged written responses to survey questions. The investigator collected data and noted the frequency and categories of data. Data analysis included interpretive explanations of observations, interviews, and archives were recorded (Creswell, 2013). The completed data analysis explicated themes and patterned regularities (Creswell, 2013). The researcher served as participant-observer by interviewing participants and by collecting data from teacher responses to interview questions. Moreover, the author developed interpretive explanations of documents. For analysis of the overall case study, research took into consideration the recommendations of Yin (2003) for considering local meanings and foreshadowed meanings in their context. The work was highly reflective, with border pedagogy (Giroux, 1991) as a framework for uncovering contextual conditions relevant to phenomena (Yin, 2003).

A search for matching patterns followed Goodrick's (2014) guidelines for cross-case analysis. Goodrick states, "Pattern matching involves comparing two or more patterns between the cases to see if they are similar or different as a step in explaining observed processes or behaviors" (2014, p. 8). The resulting cross-comparative case study of US international policies, as taught in distinctively varied locales, produced comparisons and contrasts. Accordingly, the coding of data resulted in the following emergent themes:

1. Curriculum emphasis

2. Discussions of US international policies on war and terrorism

3. Comparative perspectives of government and society 


\section{DISCUSSION}

\section{Curriculum Emphasis}

Although the amount of time devoted to discussions of US policies in Malaysian classrooms was limited in the curriculum, such topics and issues were specifically addressed in a course entitled General Knowledge, a university preparation course. Other formal discussions took place as noted in course syllabi, but there was little time for extended discussion of US policies outside of the specified school curriculum in government-supported schools.

On the other hand, the national curriculum in Mexico's public-funded schools provided for the study of US international relations in history and social studies courses at various levels. Overall, there was much interest in such discussions due the intertwined US/Mexico relations, especially on the US and Mexico border.

Canada's provinces have separate provincial curricula, so social studies and history education courses followed the Ontario curriculum in the sites studied. Canadian educators reported a high level of interest in the international affairs of the US government, again, because of the interrelationships between the US and Canada, both historically and ongoing. Teachers at the Ontario school sites reported high levels of interest and engagement in their classroom discussions of US policies.

Educators at the US school site on the US and Mexico border, by contrast, increasingly followed a test-driven curriculum, as mandated by their US state government. Discussions of the worldwide, transnational, national, and local effects of US foreign policies were discouraged in lieu of an emphasis on lessons that put their state government and policies at the center of the curriculum. State assessments placed special emphasis on state history, government, geography, and economics. Although students demonstrated a high level of interest in US and Mexico relations, in particular, there was very little time devoted to such discussions in the state curriculum. In effect, discussions of US international policies and issues were de-emphasized in favor of a testing system that placed an emphasis on state-driven agendas.

\section{Discussions of US international policies on war and terrorism}

Educators in Malaysia revealed students and classroom discussions centered around sympathy for the human casualties immediately after the September $11^{\text {th }}, 2001$ attacks on US targets. After the immediate post-9/11 period of compassion for their US counterparts' losses, sentiments shifted toward hostility as the War in Iraq commenced. Classroom discussions of US courses of action, including its war actions and justifications for its "War on Terror" reflected Prime Minister Mahathir's declaration of the US being in violation of international laws. Educators reported that students believed that US foreign policies were designed solely to favor US interests, and the US had its own definition of terrorism and terrorist activities.

Educators in Mexico shared that their students, too, were originally empathetic to the suffering of those in the US who were affected by the 9/11 incursions. However, the tone of classroom discussions shifted dramatically after the bombings and ground invasion became full warfare in Iraq. Educators and their students discussed how the US seemed to be embarking on wars without any sort of end in sight, and because of these international policies their neighbor to the north, including a large populations of Mexican background who were serving in the military or were simply US residents, would be facing never-ending terrorism because of the US government policies.

Canadian teachers also discussed how there was a shift in the tone of classroom discussions immediately post-9/11 and once the Iraq War began. There was almost unanimous opposition to the War in Iraq among the discussants, teachers and students alike, over the US-sponsored invasion of Iraq. On the contrary, Canada militarily supported the US efforts in Afghanistan as necessary measures to prevent a complete takeover of the Afghan government by the Taliban or pro-Al Queda combatants. Public support for Canada's involvement in Afghanistan waned as Canada's own war losses in terms of human casualties increased. 
The general consensus among the US social studies educators was that there was a reluctance to discuss the US wars in Iraq and Afghanistan in their classrooms. There were multiple reasons for this de-emphasizing of all recent US international polices, and especially the ongoing wars. First, the state social studies curriculum put greater emphasis on state and US domestic policies. In this manner, students were fully aware of the fact that the recent US wars, campaigns on terrorism, and current US international issues resulting from US policies would not be addressed on their high-stakes examinations. Second, there may have been a reluctance on the part of the teachers to explore the unfinished business of US wars and campaigns on terrorism, due to their own lack of knowledge of intricacies. Some US educators made personal choices to not engage in discussions they believed may be misinterpreted as overly sensitive or offensive to members of the school administration and local school district, parents, and students. Third, students rarely seemed willing to volunteer their attitudes and positions toward the current US wars and efforts to curb terrorism from other seemingly remote parts of the world, unless the students had family members who were serving as active military and were stationed in countries such Iraq, Afghanistan, or other countries in military installations. Rather, students sought to pose questions of why drug cartel violence on the US and Mexico border was not being addressed by the US government as a form of terrorism. Educators noted the importance of being able to address the importance of such international issues that affected many of their students on a daily basis. At the same time, teachers and administrators offered that attention to such local, international issues and associations to wider global issues and contexts, receive short shrift in the social studies curriculum because of the high-stakes, test-driven nature of their courses. Students seek to engage in discussions of US international policies and issues, but are afforded little opportunity for such involvement.

\section{Comparative perspectives of government and society}

Overall, discussions of US foreign policies in Malaysian classrooms moved toward concerns for their own nation's stability being threatened. The basic preoccupations were, as a Muslim-majority country, their inhabitants may have to face increased radicalism within their own country's borders while the US continues to engage in warfare, under the auspices of the "War on Terrorism." Educators and students alike expressed the need to address the root causes of terrorism, rather proceed with shortsighted policies that are designed to rally constituents around aggressions based on jingoistic declarations. In this manner, long-term solutions to conflicts have proved to be unattainable.

In the participating Mexican schools educators reported that discussions moved away from seeing the US as a model for resolving conflict with its international policies. Educators, in fact, noted that some students argued that current problems in the US were the result of the nation's past and current international policies. To further clarify, students shared sentiments of the US being in a position to reap what it has sown in terms its past dealings with other countries, and in a sense expressed fatalistic views toward issues the US must manage, including racial tensions, school violence, and wars with no clear end in sight. Some students believed that the US, as a superpower, was crumbling from within and its citizens should pay heed to lessons of history, and that the US was, essentially, the "new Rome."

Interviewees and study participants in eastern Ontario, Canada, pointed out that comparative discussions of US policies often revolved on differences and concerns over the major influences of the US media and US pop culture. As all of the Canadian school sites were situated in close proximity to the US border, educators and students were in a position to frequently travel to US locations, and make comparisons and contrasts with US lifestyles and educational settings and the Canadian equivalents. As all of the participating Canadian communities had access to the US media and pop cultures, there were concerns over the US cultural influences and policies that directly affected their livelihoods and lifestyles. Classroom discussions also moved in the direction of how US and Canada had unresolved treaty issues that received little attention in the US.

Students at the US school site expressed their concerns for border drug cartel violence, and how ongoing criminal activity affected families on both sides of the US and Mexico border. Many students either lived on the Mexican side of the US border and crossed the international border to 
attend school at the US school site, or they had relatives who lived in the nearby Mexican city and state. Educators reported that their students were eager to discuss how US international policies with Mexico and other countries, such as NAFTA, affected their daily lives. Because of state mandates that restricted the social studies curriculum, teachers and administrators at the US school site maintained there was little time for in-depth discussions on such matters of interest to the students.

Of particular importance are the comparative discourses lacking in the US case study. Accordingly, the following issues need further attention in the state curriculum:

- The legality of wars

- Treaty issues

- Immigration policies

- International perspectives of US society and societal issues

- Crime, including white collar corruption and violence

- Critiques of the mainstream media and pop culture

- The root causes of terrorism

\section{The Urgency of Critical Border Praxis}

In their groundbreaking study Bowles and Gintis (1976) argued that social conditions have been created by self-serving hierarchal, corporate, and military-industrial-congressional complex interests in our present-day educational institutions. Critical border dialogism offers the conviction that societal woes can, indeed, be addressed and ameliorated through quality educational experiences. Through this approach we learn beyond our own political, geographic, historical, and philosophical borders. We must contemplate the multiplicity of voices, including the counter-hegemonic spaces of nepantla and dialogic feminism. Pragmatic hope offers a vision for the struggles that lay ahead for individuals and educational institutions that bridge local understandings with global interconnectedness. Educators and cultural workers need to engage in dialogue on the impact of cross-border conflicts for societies. There must be a deliberation on the economic, cultural, and political ramifications of transborder migrations and interactions. In terms of schools and the school curriculum, critical border dialogism and, ultimately, critical border praxis must engage professional educators and cultural workers in key roles of determining what is included or omitted from curricula. This stands in contrast to present conditions where lobbyists, textbook publishers, corporate sponsors, and policymakers are responsible for key decisions regarding curricula.

Critical border praxis, in particular, offers opportunities for educators, students, cultural workers, community leaders, and representatives of states and nations to come together for dialogue on the common goals for an era of security and relative peace. As part of critical border praxis education must reach out to those considered unreachable in the past. Transnational educational exchanges previously deemed impossible must be held possible. For critical border praxis to be effective in its educational goals, anti-intellectualism should be replaced with access to first-rate, rigorous education. Contrary to the rhetoric that has been put forth by so-called education reformers, this sort of quality should not be hindered by the current push to drain public education from its resources. Support for public education stands in stark contrast to the increasing financial support and provisions for less-regulated charter schools or privately-sponsored academies, which tend to divert already meager funding for public schools. On the contrary, all too often corporate or other non-public school interests further their agendas without sufficient state government oversight, thus reinforcing Bowles and Gintis' (1976) correspondence principle and Bourdieu's (1977) theories of cultural reproduction. There must be a shift toward first-rate public education for students regardless of their social economic status. Quality education must be defined as something more than highly proficient standardized test scores. Critical border praxis is a concerted and mindful attempt to promote transnational understandings and models for change and peace. Critical border praxis incorporates broader visions and worldviews than those limited to personal, group, or special interests. Educational research can inform us of how critical border praxis is better facilitated. 
Accordingly, there is a need to consider the following questions:

1). How can educational systems promote deeper understandings of the root causes of international conflicts?

2). How can educators teach of the benefits of proactive stances to promote long term stability and reduce the likelihood of future violence and wars?

3 ). What role should education play in developing rich understandings across physical, political, technological, ecological, and ideological spaces and borders?

4). How can critical border praxis influence policymakers?

5). How does critical border praxis serve as pre-emptive action against inequality and social injustice?

6). How do we move toward to a vision for a Pax Universalis, or a world truly reconstructed socially and politically based on mutual responsibilities, goals, and objectives?

\section{New Beginnings}

A critical border praxis engages the educational community with discourses in issues facing our dynamic, fluid border environs. It is through a critical border praxis that we can begin to pursue utopic ideals, no matter how unattainable those embodiments may seem. Critical border praxis provides conditions in which we, as educators and members of diverse communities of learners, are brought in from the margins to cross borders and broaden our possibilities to achieve what had been considered the unattainable. At local, state, and national levels resources need to be redirected toward educational efforts. Comparative, transnational critical border praxis reinforces and helps clarify the role of education, formal and informal, to influence individual thinking one-by-one, educate school-by-school, affect community-by-community, persuade policy makers state-by-state, and to transform country-by-country on the road to an enduring Pax Universalis.

\section{CONCLUSION}

The findings of this study support what Nelles (2003) noted after the September 11, 2001, attacks:

Ironically, within days of 9/11, outpourings of sympathy came from around the world, some even saying, "We are all Americans now." Within a year the United States had squandered most international goodwill and generated unprecedented anti-American sentiments from millions of people in scores of countries. (p. 238).

Thus, if genuine change is to occur, the present US educational system must play a significant role in investigating and addressing the root causes of global conflicts (Cashman, 2013). Through the varied lenses of border pedagogy educators should look critically at policies that separate us and begin to understand what Hampton, Ligouri, and Rippberger (2003) describe as the "wedges that educational and power systems push between children and quality educational experiences." Border pedagogy serves as a useful framework for transnational comparisons of curricula, and a subsequent broadened understanding of what curricula should embody (See Figure 1). 


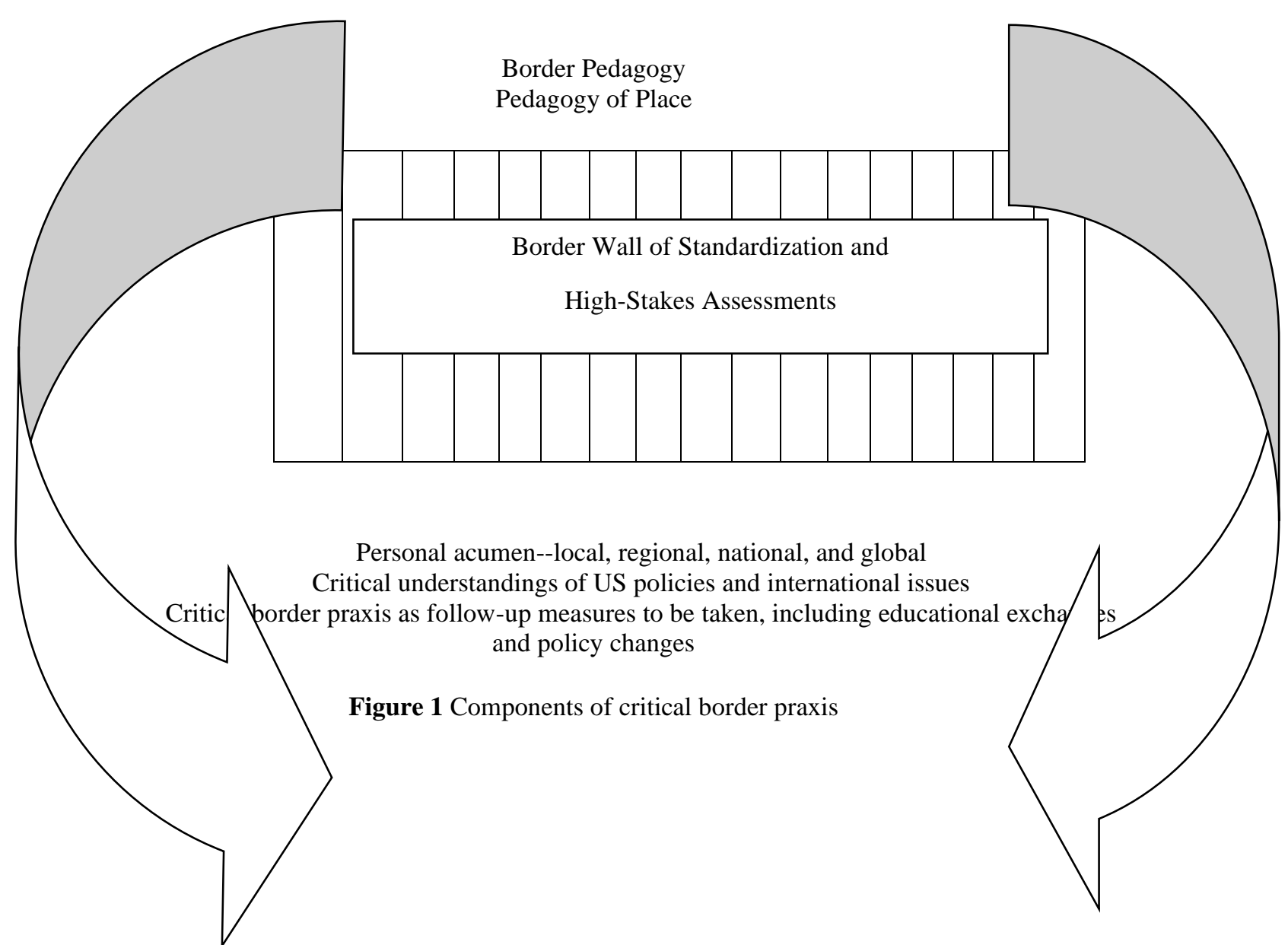

\section{REFERENCES}

Abraham, S. (2014). A nepantla pedagogy: Comparing Anzaldua's and Bakhtin's ideas for pedagogical and social change. Critical Education, 5(5), 1-19.

Anzaldúa, G. (1987). Borderlands/La frontera: The new mestiza. San Francisco, CA: Aunt Lute Books.

Anzaldúa, G. (2002). Now let us shift...the path of conocimiento...inner work public acts. In G. Anzaldúa \&

A. Keating (Eds.), This bridge we call home: Radical visions for transformation (pp. 540-577). New York: Routledge.

Bakhtin, M. M. (1981). The dialogic imagination (C. Emerson \& M. Holquist, Trans.). Austin, TX: University of Texas Press. (original work published 1975).

Bourdieu, P. (1977). Cultural reproduction and social reproduction. In J. Karabel \& Halsey, A. H., (Eds.), Power and Ideology in Education. Oxford, UK: Oxford University Press.

Bowles, S., \& Gintis, H. (1976). Schooling in capitalist America: Educational reform and the contradictions of economic life. New York: Basic Books.

Cashman, T. G. (2013). Border pedagogy as a conduit: Comparing the perspectives of educators in Malaysia, Mexico, and Canada. Multicultural Education, 20 (2), 2-9.

Cashman, T. G. (2015). Developing a critical border dialogism: Learning from fellow educators in Malaysia, Mexico, Canada, and the United States. Charlotte, NC: Information Age.

Cervantes-Soon, C. G. \& Carrillo, J. F. (2016). Toward a pedagogy of border thinking: Building on Latin@ students' subaltern knowledge. High School Journal, 99 (4), 282-301.

Clark, K., \& Holquist, M. (1984). Mikhail Bakhtin. Cambridge, Mass: Belknap Press of Harvard University Press. 
Cline, Z., \& Necochea, J. (2003). Education in the Borderlands: A border pedagogy conceptual model. El Bordo: Retos de Frontera, 6 (11), 43-52.

Creswell, J. W. (2013). Qualitative inquiry \& research design: Choosing among five approaches ( $3^{\text {rd }}$ Ed.). Thousand Oaks, CA: Sage.

Darling-Hammond, L., \& McCloskey, L. (2011). Assessment for learning around the world: What would it mean to be internationally competitive? In A. C. Ornstein, E. F. Pajak, \& S. B. Ornstein (Eds.), Contemporary issues in curriculum (2nd ed., pp. 336-347). Upper Saddle River, NJ: Pearson.

Davis, O. L., Jr. (2005). Where is the Iraq War in the curriculum this year? Or is it missing? Journal of Curriculum and Supervision, 20 (3), 183-187.

Delanty, G. (2006). The cosmopolitan imagination: Critical cosmopolitanism and social theory. British Journal of Sociology, 57 (1), 25-47.

Epstein, E.H. (2008) Setting the Normative Boundaries: crucial epistemological benchmarks in comparative education, Comparative Education, 44(4), 373-386. http://dx.doi.org/10.1080/03050060802481405

Flinders, D.J. (2006). We Can and Should Teach the War in Iraq, Educational Digest, 71 (5), 8-12.

Garza, E. (2007). Becoming a border pedagogy educator: Rooting practice in paradox. Multicultural Education, 15 (1), 2-7.

Giroux, H. A. (1988). Teachers as intellectuals: Toward a critical pedagogy of learning. Westport, CT: Bergin \& Garvey.

Giroux, H. A. (1991). Border pedagogy and the politics of postmodernism. Social Text, 28, 51-67.

Giroux, H. A. (2005). Border crossings: Cultural workers and the politics of education ( $2^{\text {nd }}$ Ed.). New York: Routledge.

Goh, P. S. C., \& Wong, K. T. (2015). Exploring the challenges for teacher educators. Journal of Research, Policy and Practice of Teachers and Teacher Education, 5 (1), 37-45.

Goodrick, D. (2014). Comparative case studies, Methodological briefs: Impact Evaluation 9, Florence, IT: UNICEF Office of Research.

Gruenewald, D. A. (2003). The best of both worlds: A critical pedagogy of place. Educational Researcher, 32(4), 3-12.

Hampton, E., Liguori, O., \& Rippberger, S. (2003). Binational border collaboration in teacher education. Multicultural Education, 11 (1), 2-10.

Holquist, M. (2002). Dialogism: Bakhtin and his world (2nd ed.). New York: Routledge.

Hoon, C.L., Dziauddin, M. F., Jabar, B., Daud, M. N., Abd Rahman, N. F., \& Othman, Z. (2014). Social science literacy among form four students in Malaysian secondary schools. Journal of Research, Policy and Practice of Teachers and Teacher Education, 4 (2), 59-72.

James, W. (1906). What pragmatism means. Retrieved from http:// www.marxists.org/reference/subject/philosophy/works/us/james. htm

Kliebard, H. M. (2004). The struggle for the American curriculum, 1893-1958. New York, NY: RoutledgeFalmer.

Koopman, C. (2006). Pragmatism as a philosophy of hope: Emerson, James, Dewey, and Rorty. Journal of Speculative Philosophy, 20 (2), 106-116.

Maffie, J. (2007). The centrality of nepantla in conquest-era Nahua philosophy. Nahua Newsletter, 44, 11-22. Retrieved from http:// www.nahuanewsletter.org/nnarchive/newsletters/Nahua44.pdf

Mignolo, W. D. (2000a). The many faces of cosmo-polis: Border thinking and critical cosmopolitanism, Public Culture, 12 (3), 721748.

Mignolo, W. D. (2000b). Introduction: From cross-genealogies and subaltern knowledges to nepantla. Nepantla: Views from South, 1 (1), 1-8.

Necochea, J., \& Cline, Z. (2005). Borderland education and teacher education reform in California: Unfulfilled promises. Journal of Borderlands Studies, 20 (1), 129-141.

Nelles, W. (2003). Comparative education, terrorism and human security: From critical pedagogy to peacekeeping. New York: Palgrave MacMillan.

Nolan, C., \& Stitzlein, S.M. (2011). Meaningful hope for teachers in times of high anxiety and low morale. Democracy and Education, 19 (1), 1-11.

Phillips, D., \& Schweisfurth, M. (2006). Comparative and international education: An introduction to theory, method, and practice. London, UK: Continuum.

Puigvert, L. (2012). The dialogic turn: Dialogue or violence? International and Multidisciplinary Journal of Social Sciences, 1 (1), 78-96. doi: 10.4471/rimcis.2012.04

Ratnavadivel, N., Nagappan, R., Dawi, A. H., \& Lim, C. H. (2014). The implications of a changing value system for policy and practice of teacher education curriculum in Malaysia. Journal of Research, Policy and Practice of Teachers and Teacher Education, 4 (2), 45-58. 
Reyes, M. D. L. (2005). Introduction to the special issue: Educational lives on the border. Journal of Latinos and Education, 4 (3), 149-152.

Romo, J.J., \& Chavez, C. (2006) Border pedagogy: A study of pre-service teacher transformation. The Educational Forum, 70, 142-153.

Rorty, R. (1999). Philosophy and social hope. New York: Penguin Books.

Rothstein, R. (2015, April 3). Taking the fall in Atlanta. Economic Policy Institute. Retrieved from http://www.epi.org/blog/takingthe-fall-in-Atlanta

Shade, P. (2001). Habits of hope: A pragmatic theory. Nashville: Vanderbilt University Press.

Yaeger, P. (1991). Afterword. In D. M. Bauer \& S. J. McKinstry (Eds.), Feminism, Bakhtin, and the dialogic (pp. 239-245). Albany: State University of New York Press.

Yin, R. K. (2003). Case study research: Design and methods. Thousand Oaks, CA: Sage Publications. 